\title{
Primary DNA Damage But Not Mutagenicity Correlates with Ciprofloxacin Concentrations in German Hospital Wastewaters
}

\author{
A. Hartmann, ${ }^{1}$ E. M. Golet, ${ }^{2}$ S. Gartiser, ${ }^{3}$ A. C. Alder, ${ }^{4}$ T. Koller, ${ }^{1}$ R. M. Widmer ${ }^{1}$ \\ ${ }_{1}^{1}$ Institute for Hygiene and Applied Physiology, Environmental Hygiene Group, ETH Zürich, Clausiusstr. 25, CH-8092 Zürich, Switzerland \\ 2 Universitat de Girona, Dpt. de Química, Facultat de Ciències, Campus Montilivi, E-17071 Girona, Catalunya, Spain \\ ${ }^{3}$ Hydrotox GmbH, Bötzingerstr. 29, D-79111 Freiburg, Germany \\ 4 Swiss Federal Institute for Environmental Science and Technology (EAWAG), CH-8600 Dübendorf, Switzerland
}

Received: 8 March 1998/Accepted: 27 August 1998

\begin{abstract}
Recently, we showed for the wastewater of a large Swiss university hospital that primary DNA damage, assessed by a bacterial SOS repair assay (umuC test), could be largely assigned to a specific class of antibiotics, the fluoroquinolones (FQs) (Hartmann et al. [1998] Environ Toxicol Chem 17:377382). In an attempt to confirm the significance of FQs for the bacterial DNA damaging effects in native hospital wastewaters, 25 samples from five German clinics were screened in this study by the umuC test. The results were compared to HPLC-derived concentrations of ciprofloxacin, an important member of the FQs. Ten samples $(40 \%)$ were umuC-positive and ciprofloxacin concentrations ranged from 0.7 to $124.5 \mu \mathrm{g} / \mathrm{L}$ $(n=24)$. Primary DNA damage, as indicated by the umuC test, correlated strongly with ciprofloxacin concentrations in a logistic, dose-dependent manner $\left(r^{2}=0.896\right)$, almost irrespective of the use of S9 metabolic activation. The lowest observed effect concentration (LOEC) for ciprofloxacin was $5.2 \mu \mathrm{g} / \mathrm{L}$ (+S9) and $5.9 \mu \mathrm{g} / \mathrm{L}(-\mathrm{S} 9)$. Similar to our previous findings, these results indicate that positive umuC results in hospital wastewater are strongly dependent on the presence of fluoroquinolone antibiotics. In a second part of the study, previously generated Ames and V79 chromosomal aberration data of the same samples (Gartiser and Brinker [1995] in Umweltbundesamt Texte 74/95) were compared with the newly generated results. Neither the mutagenic effects detected by the Ames assay $(8 \%, n=25)$ nor the positive V79 results $(46 \% n=13)$ seemed to be caused by ciprofloxacin. Therefore, the Ames and V79 results suggest the presence of additional mutagens that are yet to be identified.
\end{abstract}

There is growing evidence for the release of significant amounts of pharmaceuticals into the aquatic environment after their application and passage through the body (recently reviewed by Halling-Sorensen et al. 1998). Besides nonpoint sources such as domestic sewage, hospital wastewater has been discussed as an

Correspondence to: A. Hartmann; e-mail: hartmann@iha.bepr.ethz.ch important point source for pharmaceuticals. Many drugs used in hospitals (e.g., antibiotics, cytostatic drugs) are designed to exhibit DNA damage toward bacteria or eukaryotic cells, raising concern about the human and ecological hazard of hospital wastewater (Gartiser et al. 1994; Giuliani et al. 1996). Although up to the present no study called for an urgent need to separate hospital wastewater from municipal wastewater, authorities in some countries are considering whether hospital wastewater must be classified as a potential source for hazardous substances. Concern about its environmental impact has been raised not only due to the genotoxic and ecotoxicological effects found in different studies but also because of the elevated concentrations of detergents, disinfectants, and adsorbable organic halogenated compounds (AOX) (Gartiser and Brinker 1995; Vanrolleghem et al. 1996; Ziegler et al. 1997).

In a recent study performed in a large Swiss university hospital, we could show that genotoxic effects in untreated hospital wastewater obtained by the umuC test are caused mainly by fluoroquinolone antibiotics (FQs), especially ciprofloxacin (Hartmann et al. 1998). In this study, we wanted to get further evidence for the specific induction of the umuC test by FQs in hospital wastewater. We investigated umuC effects and ciprofloxacin concentrations in wastewater samples of five German hospitals, which had previously been screened for mutagenicity and clastogenicity in the Ames and V79 chromosomal aberration assay, respectively (Gartiser and Brinker 1995). Based on the published literature, FQs were not expected to be main causative agents of either V79 effects (Takayama et al. 1995; Curry et al. 1996) nor Ames (TA 98 and TA100) mutagenicity (Gocke 1991; Power and Phillips 1993). The data support this as well as the specific response of the umuC to ciprofloxacin. However, they suggest the presence of additional, not yet identified mutagens.

\section{Materials and Methods}

\section{Chemicals}

All chemicals and reagents used were according to Gartiser and Brinker (1995) and Hartmann et al. (1998), respectively. Ciprofloxacin 
(1-cyclopropyl-6-fluoro-1,4-dihydro-4-oxo-7-(1-piperazinyl)-3- quinolinecarboxylic acid), CAS-Nr. 85721-33-1, was from Bayer AG, Wuppertal, Germany.

\section{Sampling of Hospital Wastewater}

Sampling was done as described in detail in Gartiser and Brinker (1995). In brief, wastewater samples originated from five different hospitals in the south of Germany and were taken time proportionally between April 1992 and November 1994. Composite samples were prepared by discontinuously collecting $70-\mathrm{ml}$ aliquots every $10 \mathrm{~min}$ using an automated sampler. Daytime composite samples contained aliquots from 6:00 a.m. to 8:00 p.m., night hour samples from 8:00 p.m. to 6:00 a.m. Samples were stored at $-20^{\circ} \mathrm{C}$ immediately after sampling.

\section{High-Performance Liquid Chromatography (HPLC)}

HPLC analysis was done according to Hartmann et al. (1998). The HPLC system consisted of a Jasco 851-AS autosampler, two Jasco PU-980 gradient pumps, and a Jasco FP-920 fluorescence detector (OmniLab AG, Mettmenstetten, Switzerland). Samples were filtered through $0.45-\mu \mathrm{m}$ Sartorius cellulose acetate filters, $\emptyset 12 \mathrm{~mm}$, before being analyzed by HPLC. The limit of quantification was $0.5 \mathrm{ng} / \mathrm{ml}$ (signal to noise ratio $=10$ ).

\section{Assay for Primary DNA Damage}

The umuC assay was performed as described in Hartmann et al. (1998), with 2-aminoanthracen and mitomycin $\mathrm{C}$ as positive controls with and without S9, respectively. For metabolic activation, $20 \mu \mathrm{l}$ of $S 9 \mathrm{mix}$ (10\% liver extract of Aroclor 1254-induced male Sprague-Dawley rats, in standard S9 buffer) (Ames et al. 1975) was added to a total assay volume of $0.5 \mathrm{ml}$. An induction factor of two was defined as the limit for a significant increase in primary DNA damage.

\section{Mutagenicity Assays}

Ames Assay. A simplified version of the OECD guideline 471 (OECD 1983a) was used to perform the Ames test, using the strains TA 98 and TA 100 with and without metabolic activation (for details see Gartiser and Brinker 1995). Wastewater samples were sterile filtered $(0.45-\mu \mathrm{m})$ and 0.125 to $1 \mathrm{ml}$ of sample was applied per assay. Experiments were repeated five times. According to the suggestions of Miltenburger and Müllerschön (1989) and the preliminary DIN-standard protocol DINUA-12 (DIN 1994), results were judged positive when the mutation rate exceeded the spontaneous rate by a factor of two, and a dose-response relationship could be found. Water was used as negative control and benzo(a)pyrene or condensed cigarette smoke as positive control.

V79 Chromosomal Aberration Assay. The V79 assay was performed according to the OECD guideline 473 (OECD 1983b) and to the suggestions of Miltenburger and Müllerschön (1989), without metabolic activation. Wastewater samples were sterile filtered and tested in three concentrations. As for the Ames test, a positive mutagenic effect was defined as at least a twofold increase in mutagenic events compared with the mean mutation rate of the negative controls plus one standard deviation ( $S D=32 \%, \mathrm{n}=12$ ), paralleled by a dose response. Ethylmethansulfonate was used as positive, tapwater as the negative control. Only well-spread and clearly shaped metaphase chromosomes were used for statistical counting. A toxic effect was assumed (and the results rejected) when the mitotic indices of the fixated cells were below $1 \%$ (the control value).

\section{Data Analysis}

Nonlinear regression analysis was done using Microcal Origin version 4.1 (Microcal Software, Northampton, MA). For logistic curve fitting, the Levenberg-Marquardt Chi-square-minimization method was used. To assess fitting quality, the $95 \%$ confidence bands, the sum of square residuals (SSR) and the nonlinear correlation coefficients $\left(\mathrm{r}^{2}\right)$ were calculated. Parameters describing the fitted logistic function were used as commonly defined: A1 (initial $y$ ), A2 (final $y$ ), $x_{0}$ (center), $p$ (power).

\section{Results}

\section{Determination of Ciprofloxacin and Correlation with umuC Activity}

Twenty-five composite wastewater samples originating from different wastewater streams of five German hospitals were subjected to the umuC test. For all 25 samples, Ames data with TA 98 and TA 100 existed, and 13 samples had previously been analyzed for chromosomal aberration in the V79 assay (Gartiser and Brinker 1995). DNA-damaging activity in the umuC test was found in 10 of the 25 composite samples (Table 1), with induction factors (IF) reaching a maximum of 14. Metabolic activation had no relevant effect on the potential to induce primary DNA lesions (see Figure 1). Typically, the addition of S9 slightly increased the genotoxic effects.

For the wastewater of a university hospital we recently demonstrated that ciprofloxacin, a widely used fluoroquinolone antibacterial drug, seems to be the main cause of umuC genotoxicity (Hartmann et al. 1998). Therefore, ciprofloxacin was analytically determined by reversed-phase HPLC. The antibiotic could be detected in all of the 24 samples that had been tested (Table 1). Concentrations ranged from $0.7 \pm 0.1$ to $124.5 \pm 5.9 \mathrm{ng} / \mathrm{ml}$, with a median of $3.1 \pm 0.2 \mathrm{ng} / \mathrm{ml}$. Primary DNA damage in the umuC test (expressed as IF) and ciprofloxacin concentration correlated in a dose-dependent manner, which was best described by a logistic function with the defining parameters shown in Figure $1\left(\chi^{2} \leq 1.53, r^{2}=0.896\right)$. Using an IF of two as the limit of effect, the calculated LOEC for ciprofloxacin in the wastewater samples was 5.2 and $5.9 \mu \mathrm{g} / \mathrm{L}$ with and without S9, respectively. This corresponds well with the value of $5 \mu \mathrm{g} / \mathrm{L}$ previously found for ciprofloxacin in distilled water (Hartmann et al. 1998) and indicates no substantial masking or enhancing of the umuC effects by the wastewater matrix.

\section{Comparison of umuC Data with Mutagenicity Assay Results (Ames, V79)}

Since the samples investigated in the umuC assay had been previously tested for mutagenicity in the Ames and V79 chromosomal aberration test, we wanted to assess the role of FQs for these earlier established mutagenic effects. The mutage- 
Table 1. Summary of the results of in vitro DNA damage testing and ciprofloxacin concentrations of hospital wastewater samples

\begin{tabular}{|c|c|c|c|c|c|c|c|c|c|c|c|c|c|}
\hline \multirow[b]{3}{*}{ UmuC } & \multirow[b]{3}{*}{ Ames } & \multirow[b]{3}{*}{ V79 } & & & & & & & & \multicolumn{4}{|c|}{ Partial Streams } \\
\hline & & & \multicolumn{7}{|c|}{ Main Sewer } & \multirow{2}{*}{$\begin{array}{l}\text { Coulecung } \\
\text { Sewer } \\
\text { UHF } \\
\text { S } 10-11\end{array}$} & \multirow{2}{*}{$\begin{array}{l}\text { EN 1 } \\
\text { Clinic } \\
\text { UHF } \\
\text { S 7-9 }\end{array}$} & \multicolumn{2}{|c|}{ Medical Sector } \\
\hline & & & $\begin{array}{l}\text { UHF } \\
\text { S 2,3,5 }\end{array}$ & $\begin{array}{l}\text { RHF } \\
\text { S 28 }\end{array}$ & $\begin{array}{l}\text { RHO } \\
\text { S 32-34 }\end{array}$ & $\begin{array}{l}\text { CTB } \\
\text { S } 37\end{array}$ & $\begin{array}{l}\text { RHL } \\
\text { S } 39\end{array}$ & $\begin{array}{l}\text { LCBB } \\
\text { S } 40\end{array}$ & $\begin{array}{l}\text { RHW } \\
\text { S } 41\end{array}$ & & & $\begin{array}{l}\text { UHF } \\
\text { S 12-15 }\end{array}$ & $\begin{array}{l}\text { RHO } \\
\text { S } 35\end{array}$ \\
\hline \multirow[t]{4}{*}{-2} & & 0 & $\begin{array}{l}3: 1.2^{b} \\
5: 5.4\end{array}$ & & $33: 2.2$ & & & $40 \mathrm{~N}: 4.9$ & $41 \mathrm{~N}: 3.2$ & $10: 1.8$ & & & \\
\hline & & & $2: 1.3$ & 28: 0.7 & $\begin{array}{l}32: 3.2 \\
34: 1.0\end{array}$ & $37: 1.4$ & $39: 3.9$ & $40: 3.9$ & $41: 1.2$ & & $9: 1.4$ & & \\
\hline & - & (+) & & & & & $39 \mathrm{~N}: 8.7$ & & & 11: 13.3 & $8: 26.2$ & $\begin{array}{l}15: 124.5 \\
12: 2.6 \\
13: 3.0 \\
14: 5.9\end{array}$ & $35 \mathrm{~N}: 22.9$ \\
\hline & $\begin{array}{l}+ \\
+\end{array}$ & $\begin{array}{l}0 \\
+\end{array}$ & & & & & & & & & $7: n d$ & & $35: 29,4$ \\
\hline
\end{tabular}

Results are grouped according to the origin of sampling and the effects in the genetic bioassays, respectively. Abbreviations of medical institutions: UHF, University hospital Freiburg; RHF, Regular hospital Freiburg; RHO, Regional hospital Offenburg; CTBF, Clinic for Tumor Biology Freiburg; RHL, Regional hospital Lahr; LCBB, Local clinic Baden-Baden; RHW, Regional hospital Wolfach; ENT, Eye, nose, and throat clinic. Sample numbers (S 2-S41) correspond to Gartiser and Brinker (1955)

${ }^{a} 0=$ not measured; $-=$ negative; $+=$ positive; $(+)=$ positive without dose response

${ }^{b}$ Normal font: sample number; italic font $=\mu \mathrm{g} / \mathrm{L}$ ciprofloxacin

c $\mathbf{N}=$ night composite sample. Day composite samples are not specially labeled

nicity data were published in detail by Gartiser and Brinker (1995) and are therefore only summarized here (the full data set has been deposited by the authors and is available on request). Two out of 25 of the composite samples were mutagenic using the standard Ames strains TA 98 and 100 (8\%, Table 1). One sample (S7) was weakly mutagenic in strain TA 100 with metabolic activation, the other one (S35) showed strong mutagenicity in strain TA 98 and TA 100 , irrespective of metabolic activation. A higher percentage of mutagenicity might have resulted if the fluoroquinolone-responsive strain TA 102 would have been used, but TA 102 is not a default strain for wastewater screening and was therefore not integrated into the study of Gartiser and Brinker. A strikingly high incidence of mutagenicity was found in the V79 chromosomal aberration assay. Six out of 13 samples tested were mutagenic, with one sample (S14) showing just a twofold increase in mutation rate but no dose response.

Out of the total of 25 samples tested, 14 samples ( $56 \%$ ) were positive in at least one assay, four samples were just mutagenic (V79-positive), and seven induced only primary DNA lesions (umuC-positive). Only three samples were both mutagenic and caused also primary DNA damage. Comparing the results of the three in vitro DNA-damage assays revealed two further aspects: First, all discordant samples between the Ames and umuC test were umuC-positive and Ames-negative (eight of 25 samples). Second, discordance between V79 and Ames was always due to V79-positive and Ames-negative results (five of 13 samples). Due to the limited number of biological data (especially V79 results), test concordance was not analyzed in more detail. A comparative (linear) correlation of V79 chromosomal aberration rates and ciprofloxacin concentration in the respective samples $(n=13)$ was not significant $\left(r^{2}=0.17\right.$, data not shown). Due to the paucity of positive Ames results, no correlation was calculated for this test.

Analysis of the different types of sampling sites (main sewer, medical sector, etc.) yielded two noteworthy trends: (1) All samples from the medical sector were umuC-positive $(n=6)$; and (2) The V79 test caused three of the four positive effects found in main sewer samples, but only two out of the 13 positive effects found in partial streams.

\section{Discussion}

Several reviews on DNA-damaging effects in wastewaters identified industrial discharges as the main point sources for primary DNA damage or mutagenicity (Houk 1992; Helma and Knasmüller 1997). Recent publications discussed hospital wastewater as an additional source for mutagenic or generally genotoxic chemicals (Gartiser et al. 1996; Giuliani et al. 1996; Steger-Hartmann et al. 1997). The results presented in this paper clearly demonstrate in vitro genotoxic and mutagenic effects in either total or partial hospital wastewater streams. In total, $56 \%$ (14 of 25) of the composite wastewater samples tested yielded primary DNA damaging or mutagenic responses in one or several of the applied bioassays. As in a preceding study (Hartmann et al. 1998), we can attribute most of the primary DNA damaging effects in the presently investigated hospital wastewater samples to a distinct class of pharmaceuticals, the FQs.

The nonlinear correlation $\left(r^{2}=0.896\right)$ between umuC induction and ciprofloxacin concentration indicates that a substantial part of the primary DNA damage is caused by ciprofloxacin. The correlation could even be underestimated given the fact that the hospitals investigated here use a broad spectrum of FQs, which contribute to primary DNA damage, but were not determined analytically. In the Offenburg Regional Hospital (RHO) for example, ciprofloxacin contributed only about $20 \%$ to the total FQ consumption, in the University Hospital of Freiburg (UHF) about 50\% (Gartiser and Brinker 1995). The analytically determined concentrations were generally within the range predicted by calculations based on consumption data, 

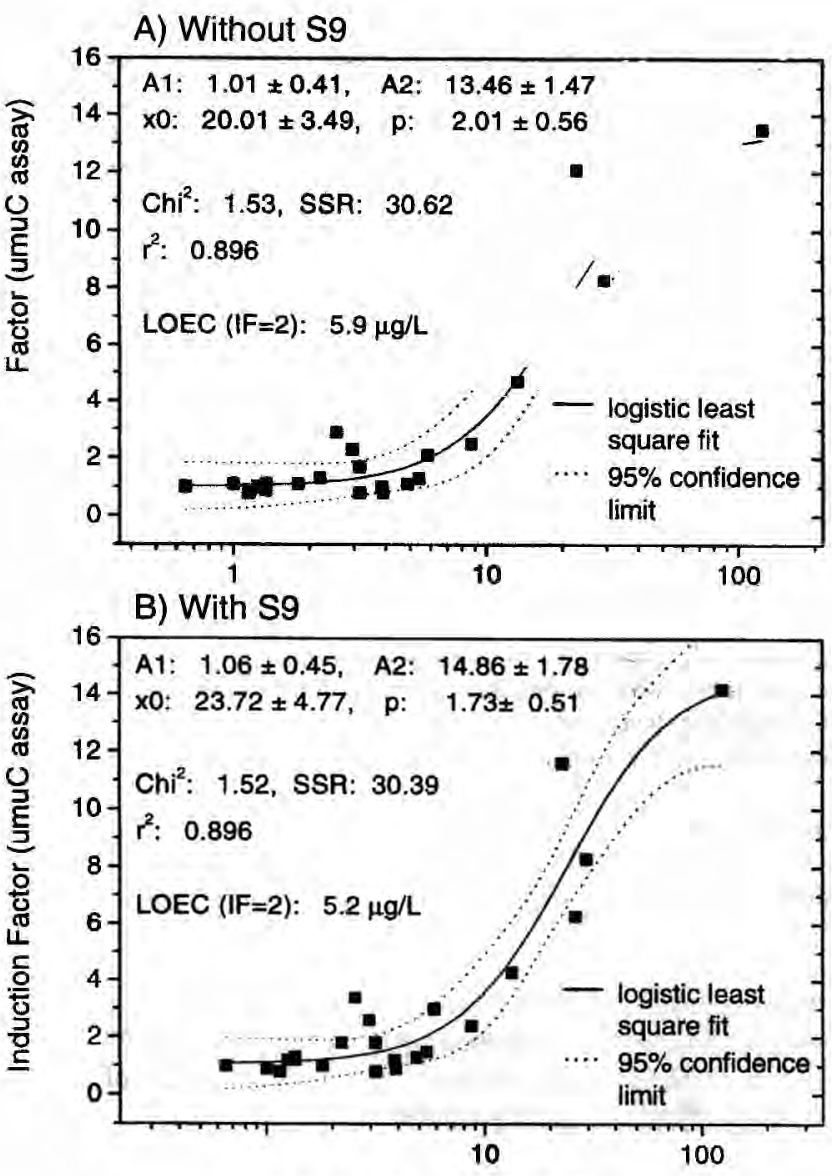

$\mathrm{ng} / \mathrm{ml}$ Ciprofloxacin (HPLC-assay)

Fig. 1. Analytical ciprofloxacin concentration determined by HPLC and primary DNA damage, given by umuC induction factor. A) without, B) with metabolic activation ( 99 rat liver extract). Solid lines indicate a logistic least square regression fit of the data, dashed lines represent the $95 \%$ confidence limit. A1, A2, x0, and p are the calculated parameters of the fitted logistic model. $\mathrm{Chi}^{2}$, SSR (sum of square residuals), and the nonlinear correlation coefficient $r^{2}$ are also given. Finally, the calculated lowest observed effect concentration (LOEC) for an induction factor of two is indicated

water consumption, and metabolic turnover rates (Gartiser and Brinker 1995). The fact that the umuC activity of wastewater samples and the correlation of primary DNA damage with ciprofloxacin concentration were almost independent of the use of $\mathbf{S 9}$ metabolic activation (Figure 1) gives additional support for FQs being the main umuC inducers: FQs act via inhibition of the bacterial gyrase rather than through direct nucleophilic interaction with DNA (Hooper 1995), their genotoxic activity being independent of metabolic activation by mixed functional oxidases. Most of the wastewaters from medicinal sectors analyzed in this study show DNA-damaging effects in the umuC test. This corresponds well with the concept of a pharmaceutical compound as the main source for primary DNA damage.

For the Ames or V79 data, no significant correlation with ciprofloxacin concentrations could be found. This is not surprising for each of these assays. It has been repeatedly shown that ciprofloxacin, as well as other FQs, does not induce Ames mutagenicity, except in strains with a functional uvrB excision repair system, e.g., TA 102 (Gocke 1991; Power and Phillips 1993; Mamber et al. 1993). This strain was not used in the study of Gartiser and Brinker (1995), which was focused on the screening for mutagenicity with the standard strains (TA 98 and 100 , according to the standard protocol DIN-UA-12 [DIN 1994]). Furthermore, FQs exhibit V79 chromosomal aberrations only at concentrations one to two orders of magnitude above the ones found in the investigated samples (Takayama et al. 1995; Curry et al. 1996). This can be explained by the much lower affinity of eukaryotic topoisomerase II to FQs compared with the bacterial gyrase. This rules out the possibility of FQs being responsible for the clastogenic effects in the investigated wastewaters.

The human genotoxic hazard posed by environmental ciprofloxacin exposure seems to be small. Preclinical and clinical studies, carried out at much higher doses, do not suggest a significant in vivo genotoxic or carcinogenic risk from ciprofloxacin (Albertini et al. 1995; references in Takayama et al. 1995; Curry et al. 1996; Shimada and Itoh 1996), with the exception of weak in vivo photocarcinogenic effects after prolonged exposure (Klecak et al. 1997). The fact that some of the hospital wastewaters nevertheless induced Ames or V79 mutagenicity clearly indicates that besides FQs there must be further, unknown genotoxins in these wastewaters. These might represent a possible human health risk or an ecological risk for aquatic organisms. As an example, many disinfectants, bleaching agents, or detergents induce DNA damage in the Ames, V79, or umuC test, although the concentrations found in wastewaters are generally below the effect limit (Gartiser and Brinker 1995).

Comparing the relative percentage of the positive results of the three in vitro assays reveals clearly more DNA damage in the V79 and umuC assay than in the Ames test. While the high rate of positive umuC data seems definitely to be due to its sensitivity to FQs, the high V79 chromosomal aberration rate suggests this assay being a more sensitive endpoint than Ames reverse mutagenicity for screening of hospital wastewaters for potential genotoxins. The significance of this sensitivity, however, is not completely clear: On the one hand, eukaryotic chromosomal aberration is certainly a more established indication of a genetic risk than DNA damage in a bacterial test organism. On the other hand, the significance of the in vitro chromosomal aberration has been critically discussed, especially the aspect of cytotoxicity control parameters. It has been suggested that the use of the mitotic index might not absolutely rule out cytotoxic effects leading to false positive results (Armstrong et al. 1992; Kramer 1993). This might be a critical point, especially for wastewater testing, where additional effects (e.g., the complex sample matrix) can infiuence the test result.

\section{Conclusions}

The in vitro data presented here suggest that hospital wastewater might be a source for DNA-damaging or mutagenic compounds. The primary DNA damaging effects, which are based on a bacterial SOS repair assay, could largely be explained by the presence of specific antibiotic drugs (fluoroquinolones). This significantly reduces the potential human genotoxic hazard, since the presently merchandised FQs are known 
to have a low eukaryotic DNA-damaging potential (Albertini et al. 1995; Shimada and Itoh 1996). Therefore, care has to be taken when the umuC test is used for environmental or human genotoxic risk assessment of hospital wastewaters. We strongly recommend obtaining analytical information about the presence of FQs in umuC-positive samples before further actions are taken. However, FQs do not explain the mutagenic effects found in the Ames and V79 chromosomal aberration assay. Therefore we cannot give the all-clear for hospital wastewater in terms of its human or ecological hazard. In the light of the present findings, the classification of hospital wastewater as a source for hazardous substances needs further discussion.

In addition, the study stresses the presently growing evidence of active pharmaceutical compounds, in this case antibiotics, being distributed into the aquatic environment by excretion after their application. The fate of these chemicals and their biological effects remain to be assessed.

Acknowledgments. The authors would like to thank $\mathbf{R}$. Willmund (Hydrotox GmbH, Germany) for mutagenicity testing and Bayer AG (Wuppertal, Germany) for providing ciprofloxacin as a reference compound. In addition, we gratefully acknowledge the stimulating feedback of two anonymous reviewers.

\section{References}

Albertini S, Chetelat AA, Miller B, Muster W, Pujadas E, Strobel R, Gocke E (1995) Genotoxicity of 17 gyrase- and four mammalian topoisomerase. II-poisons in prokaryotic and eukaryotic test systems. Mutagenesis 10:343-351

Ames BN, McCann J, Yamasaki E (1975) Methods for detecting carcinogens and mutagens with the Salmonella/mammalianmicrosome mutagenicity test. Mutat Res 31:347-64

Armstrong MJ, Bean CL, Galloway SM (1992) A quantitative assessment of the cytotoxicity associated with chromosomal aberration detection in Chinese hamster ovary cells. Mutat Res 265:45-60

Curry PT, Kropko ML, Garvin JR, Fiedler RD, Theiss JC (1996) In vitro induction of micronuclei and chromosome aberrations by quinolones: possible mechanisms. Mutat Res 352:143-150

DIN (1994) Determination of the mutagenic potential of water and wastewater using the Salmonella/microsome test. Preliminary DIN protocol UA-12, Deutsches Institut für Normung, Berlin, Germany

Gartiser S, Brinker L (1995) Abwasserbelastende Stoffe und Abwassersituation in Kliniken. In: Umweltbundesamt Texte 74/95, $A b$ schlussbericht zum F+E-Vorhaben 10206514. Umweltbundesamt, Berlin, Germany

Gartiser S, Brinker L, Erbe T, Kümmerer K, Willmund R (1996) Belastung von Krankenhausabwasser mit gefährlichen Stoffen in Sinne $\$ 7$ a des Wasserhaushaltgesetzes. Acta Hydrochim Hydrobiol 24:90-97

Gartiser S, Brinker L, Uhl A, Willmund R, Kümmerer K, Daschner F (1994) Untersuchung von Krankenhausabwässern am Beispiel des Universitäts-klinikums Freiburg. Korrespondenz Abwasser 9:16181624
Giuliani F, Koller T, Würgler FE, Widmer RM (1996) Detection of genotoxic activity in native hospital wastewater by the umuC test. Mutat Res 368:49-57

Gocke E (1991) Mechanism of quinolone mutagenicity in bacteria. Mutat Res 248:135-143

Halling-Sorensen B, Nors Nielsen S, Lanzky PF, Ingerslev F, Holten Lützhoft HC, Jorgensen SE (1998) Occurrence, fate and effects of pharmaceutical substances in the environment-a review. Chemosphere 36:357-393

Hartmann A, Alder AC, Koller T, Widmer RM (1998) Identification of fluoroquinolone antibiotics as the main source of umuC genotoxicity in native hospital wastewater. Environ Toxicol Chem 17:377382

Helma C, Knasmüller S (1997) Gentoxische Substanzen in Wässern: II. Industrielle Abwässer. UWSF-Z Umweltchem Ökotox 9:41-48

Hooper DC (1995) Quinolone mode of action. Drugs 49:10-15

Houk VS (1992) The genotoxicity of industrial wastes and effluents. Mutat Res 277:91-138

Klecak G, Urbach F, Urwyler H (1997) Fluoroquinolone antibacterials enhance UVA-induced skin tumors. J Photochem Photobiol B $37: 174-181$

Kramer, PJ (1993) Are chromosomal aberration tests in vitro particularly prone to artificial findings? In: Madle S and Müller M (eds) Current issues in genetic toxicology. BGA Schriften 1/93, MMV Medizin Verlag, München, Germany, pp 52-61

Mamber SW, Kolek B, Brookshire KW, Bonner DP, Fung TJ (1993) Activity of quinolones in the Ames Salmonella TA102 mutagenicity test and other bacterial genotoxicity assays. Antimicrob Agents Chemother 37:213-217

Miltenburger HG, Müllerschön H (1989) Genotoxizitätstests mit Zellkulturen. In: Göggelmann W et al. (eds) Abschlussbericht Forschungsvorhaben CMT 48A, Band 2, Teilbericht C. Institut für Wasser-, Boden- und Lufthygiene des Bundesgesundheitsamtes, Berlin, Germany, p 20

OECD (1983a) OECD guideline for testing of chemicals (471): genetic toxicology: Salmonella typhimurium reverse mutation assay. Organisation for Economic Cooperation and Development, Paris, France

OECD (1983b) OECD guideline for testing of chemicals (473): genetic toxicology: In vitro mammalian cytogenetic test. Organisation for Economic Cooperation and Development, Paris, France

Power EG, Phillips I (1993) Correlation between umuC induction and Salmonella mutagenicity assay for quinolone antimicrobial agents. FEMS Microbiol Lett 112:251-254

Shimada H, Itoh S (1996) Effects of new quinolone antibacterial agents on mammalian chromosomes. J Toxicol Environ Health 47:115123

Steger-Hartmann T, Kümmerer K, Hartmann A (1997) Biological degradation of cyclophosphamide and its occurrence in sewage water. Ecotox Environ Saf 36:174-179

Takayama S, Hirohashi M, Kato M, Shimada H (1995) Toxicity of quinolone antimicrobial agents. J Toxicol Environ Health 45:1-45

Vanrolleghem PA, Zaide K, Coen, F (1996) Full-scale assessment of toxic wastewaters causing change in biodegradation model structure and parameters. Wat Sci Tech 33:163-175

Ziegler M, Schulze-Karal C, Steiof M, Rüden H (1997) Reduzierung der AOX-Fracht von Krankenhäusern durch Minimierung des Eintrags iodorganischer Röntgenkontrastmittel. Korrespondenz Abwasser 44:1404-1408 